Volume 6 No. 1, Juni 2019

P-ISSN: 2406-808X // E-ISSN: 2550-0686

https://journal.iainlangsa.ac.id/index.php/ikhtibar

https://doi.org/10.32505/ikhtibar.v6i1.601

\title{
KAPASITAS ULAMA DALAM BERNEGARA
}

\author{
Muhammad Nuh Rasyid \\ Institut Agama Islam Negeri Langsa \\ muhammadnuhrasyid@iainlangsa.ac.id
}

\begin{abstract}
Abstrak
Dalam membangun bangsa yang maju besar dan beradab, agama memiliki peran yang sangat besar. Sebagai organisasi sosial keagamaan, sejak dulu ulama-ulama berperan sangat besar dalam mengayomi dan membangun masyarakat, baik melalui pendidikan, dakwah dan lain sebagainya. Peran ulama yang sedemikian besar itu diemban oleh para ulama tidak lain karena ulama adalah pewaris dari ajaran nabi. Sementara tugas ulama selain mengggali, merumuskan dan mengembangkan pemikiran keagamaan, juga memiliki tugas yang tidak kalah pentingnya dan bahkan sangat strategis yang berkaitan dengan masalah sosial dan kebangsaaan yaitu tugas membangun masyarakat dengan tujuan membentuk kepribadian. Dalam kaitan dengan masalah masyarakat, ulama masa kini memiliki beberapa tugas, salah satunya adalah pembangunan mental-spiritual, pembentukan kepribadian atau karakter masyarakat. Ini sangat penting agar lahir masyarakat yang memiliki sikap, memiliki ketegasan, memiliki prinsip serta memiliki tanggung jawab baik terhadap Tuhan dan terhadap sesama manusia serta terhadap bangsa dan Negara.
\end{abstract}

Kata Kunci: Kapasitas Ulama, Bernegara

\section{Pendahuluan}

Kita semua yang hidup di Indonesia wajib bersyukur kepada Allah Swt. karena Indonesia negara yang begitu besar anugerah yang diberikan Tuhan, termasuk pada aspek keberagaman seperti etnis, suku, budaya dan agama serta kelompok golongan masyarakat hidup dengan baik, saling berdampingan, gotong royong serta menjunjung tinggi nilai-nilai kemanusiaan tanpa melihat latar belakang. Pada tolok ukur keberagaman ini perlu kita jaga sekaligus dikelola dengan baik, sehingga dapat membangun Indonesia secara utuh. Dan justru perbedaan itu jangan sampai kita jadikan sebagai alat pemecah belah bangsa yang dapat merugikan kita semua sebagai warga negara. Oleh karena itu, Indonesia sebagai bangsa yang menjunjung tinggi nilai keberagaman berimplikasi pada harapan dan ekspektasi menjadi bangsa yang Baldatun Tayyibatun wa Rabbun Ghafur. 
Sinergitas Ulama dan Umara menjadi penting dalam membangun sebuah bangsa yang berdaulat, membangun negara yang kuat sekaligus mewujudkan arah bangsa Indonesia menjadi negara yang Baldatun Tayyibatun wa Rabbun Ghafur. Ulama, sudah gamblang dipaparkan bahwa mereka pewaris para nabi dan penyambung lidah kebenaran. Ulama mewariskan ilmu, ilmu itulah yang kemudian disampaikan kepada manusia dari masa ke masa oleh ahli ilmu, yaitu ulama. Ulama yang shaleh yaitu berakhlak mulia yang ucapannya sesuai dengan perilakunya. Ulama yang shaleh, dakwahnya mengajak kepada amar ma'ruf dan nahi munkar. Ia tidak canggung memberi nasihat dan peringatan, termasuk kepada penguasa sekalipun. Ulama dan umara terlibat dalam kebersamaan membangun negeri dan bertujuan untuk mencapai suatu kesejahteraan masyarakat yang adil dan makmur. Umara membutuhkan ulama sebagai penasehat dan juga sumber untuk mendapatkan keputusan yang dilandasai oleh hukum agama, begitupun ulama membutuhkan sosok umara untuk mendukung aktivitasnya dibidang pendidikan, peradilan, bahkan sampai kepersoalan strategis lainnya seperti membangun pondasi masyarakat berakhlak mulia.

Imam al-Ghazali mengatakan "Agama dan Negara merupakan dua hati yang tidak dapat dipisahkan." Istilah negara yang merepresentasikan peran Pemikir Agama (Ulama) dan Pemikir Negara (Umara) telah dibuktikan melalui tradisi keilmuan dan kekuasaan sejak dulu. Seperti Negara Utama (The Interests of the State) sejak dulu telah diperkenalkan oleh Filsuf Barat. Tokoh Pemikir Islam al-Farabi menyebutkan al-Madinat al-Fadhilah. Dalam bahasa sebagian filosof Yunani disebut Republika.

Pesatnya perkembangan zaman menjadikan ilmu pengetahuan dan teknologi komunikasi elektronis menjadi cepat berkembang. Komunikasi elektronis ini tidak sekedar dijadikan cara untuk menyampaikan informasi atau berita dengan lebih cepat, melainkan dapat pula mempengaruhi bahkan mengubah setiap lengkung kehidupan tanpa terkecuali lengkung-lengkung kehidupan beragama. Ketika gambar seorang selebritis ditayangkan di media, dia lebih kita terkenal dari pada wajah tetangga kita. Sesuatu telah berubah dalam kodrat pengalaman kita sehari-hari. ${ }^{1}$ Teknologi informasi dan komunikasi memang telah memberikan manfaat bagi kehidupan manusia, termasuk memberikan manfaat bagi penyiaran aktivitas kehidupan beragama, namun dapat pula menyebabkan terjadinya pergesekan nilai budaya dan agama. Pengaruh negatif yang mungkin terjadi dapat membuat orang mencari alternatif spiritualitas lain, untuk pemahaman tentang makna hidup. Alternatif ini berasal dari filsafat dan sumber-sumber lain yang dirangkum sedemikian rupa untuk mengembangkan sistem baru dari dirinya sendiri dan menjadikannya suatu dinamika kehidupan, baik dilihat dari agama itu sendiri. Bisa jadi itu dinamika tradisi agama samawi yang akan terus berlanjut dalam berbagai konteks, sebab agama samawi memiliki sifat dan nilai yang dibutuhkan manusia.

\section{Ulama Menurut Alquran}

Istilah "ulama" secara sederhana berarti orang yang mengetahui atau orang yang memiliki ilmu.Tidak ada pembatasan ilmu spesifik dalam pengertian ini. Tetapi, seiring perkembangan dan terbentuknya ilmu-ilmu Islam khususnya syari'ah atau fikih, pengertian ulama menyempit menjadi orang yang memiliki pengetahuan dalam bidang fikih. Meskipun di Timur Tengah, pengertian ulama cenderung kembali meluas mencakup

\footnotetext{
${ }^{1}$ Maryadi, Eksistensi Agama pada Era Globalisasi, (Jakarta: Paramadina, 1995), hal. 128.
} 
orang-orang yang ahli dalam ilmu agama dan ilmu-ilmu umum. ${ }^{2}$ Pengertian ulama dalam konteks Indonesia pada umumnya terbatas, masih sempit dan tetap dominan. Dengan kata lain, ulama umumnya diidentikkan dengan orang-orang yang ahli dalam bidang agama, lebih khusus lagi fikih. Tetapi, sekali lagi dalam konteks Indonesia, keahlian dalam bidang fikih saja belum cukup bagi seseorang untuk diakui sebagai ulama. Ada beberapa orang di Indonesia yang ahli dalam bidang ini, tetapi belum dipandang masyarakat luas sebagai ulama. Boleh jadi mereka lebih dipandang sebagai intelektual atau lebih popular lagi cendekiawan muslim. ${ }^{3}$

Ulama memiliki status yang sangat urgen dan posisi strategis dalam Islam. Sehingga pembahasan yang berkaitan dengan ulama tidak luput dibahas dalam Alquran, mulai dari suku katanya, sinonimnya sampai kepada karakteristiknya.

Di dalam Alquran kata ulama disebutkan sebanyak dua kali: Pertama, disebutkan dalam surat Fāthir ayat 28 dengan kata al-Ulamā, yang diawali alìf lām:

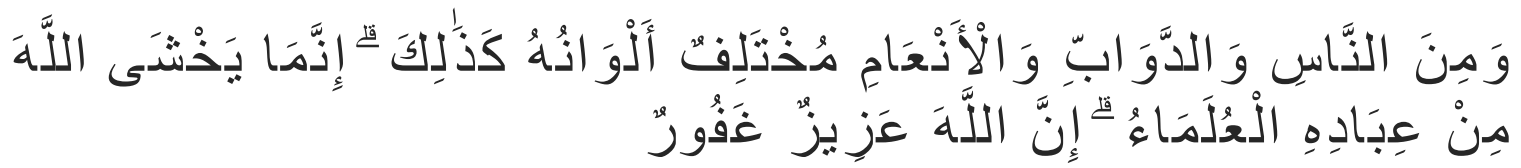

"Dan demikian (pula) di antara manusia, binatang-binatang melata dan binatangbinatang ternak ada yang bermacammacam warnanya (dan jenisnya). Sesungguhnya yang takut kepada Allah di antara hamba-hamba-Nya, hanyalah ulama. Sesungguhnya Allah Maha Perkasa lagi Maha Pengampun”

Kedua, disebutkan dalam surat asy-Syu'ara ayat 197 dengan kata Ulamā tanpa diawali dengan alīf lām tetapi disandarkan kepada Isrāīl:

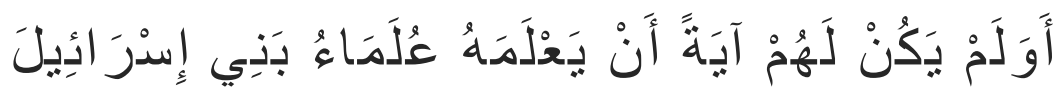

"Dan apakah tidak cukup menjadi bukti bagi mereka, bahwa para ulama Bani Israil mengetahuinya?”

Dua ayat yang menyebutkan secara sharīh (jelas) kata ulama diatas, memiliki status gramatikal bahasa arab yang sama yaitu keduanya sebagai Ma'rifat (yang diketahui atau sudah khusus maknanya). Pada ayat yang pertama dikatakan sebagai bagian dari ma'rifat karena kata ulama tersebut diawali dengan alīf lām. Sedangkan pada ayat yang kedua kata ulama tersebut di idhafahkan kepada kata setelahnya yaitu BanīIsrāīl. Dimana keduanya termasuk sebab yang mengakibatkan sebuah kalimat yang nakirah (yang belum diketahui atau umum maknanya) menjadi ma'rifah. ${ }^{4}$ Hal ini mengindikasikan bahwa agama ini memilki pandangan khusus tentang hakikat ulama.

\footnotetext{
${ }^{2}$ Burhanudin, Ulama Perempuan Indonesia, (Jakarta: Gramedia Pustaka Utama, 2002), hal. 27.

${ }^{3}$ Azra, Biografi Sosial Intelektual Ulama Perempuan: Perberdayaan Historiografi Dalam Ulama Perempuan Indonesia, (Jakarta: Gramedia Pustaka Utama, 2002), hal. 27

${ }^{4}$ Abdullah bin Hisyām al-Anshāri, Syarh Qathr an-Nadā wa Baall ash-Shadā, (Beirut: Dār al-Fikr, 2008), hal. 149-154.
} 
Untuk menjadi seorang ulama tentu tidaklah semudah membalikkan telapak tangan. Dengan asumsi rasa takut kepada Allah sebagai subtansi utamanya, sebagaimana dalam perspektif Alquran surat Fathir ayat 28, yang menjadikan rasa al-khasyyah sebagai karakteristik utama seorang ulama yang ideal. Al-khasyyah secara bahasa bentuk mashdar (kata yang datang pada urutan ketiga dalam ilmu sharaf) dari kata khasyia-yakhsyakhsyyan dan khasyatan yang artinya takut. ${ }^{5}$ Adapun secara istilah al-khasyyah adalah rasa takut yang didasari oleh ilmu pengetahuan tentang keagungan dzat yang ditakutinya dan kesempurnaan kesultanannya. Allah berfirman:

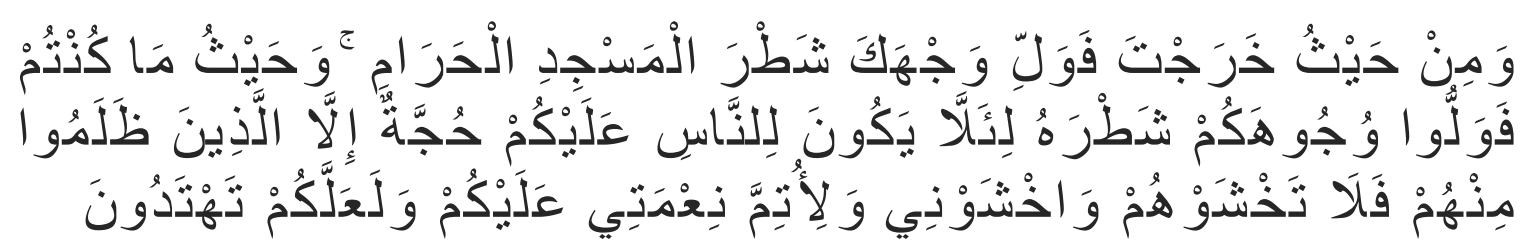

"Dan dari mana saja kamu (keluar), maka palingkanlah wajahmu ke arah Masjidil Haram. Dan dimana saja kamu (sekalian) berada, maka palingkanlah wajahmu ke arahnya, agar tidak ada hujjah bagi manusia atas kamu, kecuali orang-orang yang zalim diantara mereka. Maka janganlah kamu takut kepada mereka dan takutlah kepada-Ku (saja). Dan agar Ku-sempurnakan nikmat-Ku atasmu, dan supaya kamu mendapat petunjuk" (Surah al-Baqarah:150).

Ulama merupakan orang yang ahli dalam ilmu agama Islam. Dengan ilmu pengetahuannya, mereka memiliki rasa takwa, takut dan tunduk kepada Allah. Ulama juga memiliki pengetahuan tentang ayat-ayat Allah baik yang kauniyyah maupun quraniyah. Karena begitu khasnya posisi ulama di dalam Islam, maka tidak sulit untuk difahami kenapa ulama begitu dihormati di kalangan umat Islam, memiliki pengaruh dan membuat umat loyal terhadapnya. Dalam konfigurasi sosial kebudayaan ulama juga diangggap sebagai cultural broker (perantara budaya), ulama-lah yang mampu memberikan filterasi dari realitas sosial kebudayaan dan politik yang berkembang di masyarakat. Signifikansi peran ulama dalam kehidupan masyarakat Islam ditambah loyalitas umat terhadapnya membuat pengaruh ulama sedemikian rupa, menjadi figur strategis kerjasama baik itu kalangan penguasa maupun pengusaha. Ulama dibutuhkan dalam mendampingi dan mengarahkan umat dalam menghadapi dinamika kehidupan yang sedemikian kompleks.

\section{Peran Ulama dalam Bernegara}

Penduduk Indonesia kebanyakan memeluk agama Islam, tetapi ada agama lain yang berkembang di sini. Islam datang di Indonesia tidak terlepas dengan peran para ulama-ulama untuk menyebarkan Islam secara damai sehingga mudah diterima oleh berbagai lapisan masyarakat. Sangat penting untuk mengetahui sejarah Islam masuk di Nusantara supaya tidak kehilangan identitasnya sebagai warga Negara Indonesia. Islam yang ada di Indonesia ini berbeda dengan Islam yang ada di Mesir, Arab Saudi, Palestina

${ }_{5}^{5}$ Munawwir, Kamus al-Munawwir Arab-Indonesia Terlengkap, (Surabaya: Pustaka Progressif, 1997), hal. 342. 
dan lain sebagianya. Beberapa tahun terakhir ini, sejumlah Negara di Timur Tengah dan Eropa sering mengundang cendekiawan Muslim Indonesia. Dengan tujuan mereka ingin mengetahui lebih dalam tentang Islam yang berkembang di Indonesia atau Islam Nusantara yang wajahnya sama dengan Islam wasathiyah, yaitu Islam yang ada di tengah, tidak berada dalam kutub ekstrem dalam pemahaman dan pengalamannya. Timur Tengah dan Eropa kagum dengan Islam di Indonesia karena dapat hidup rukun dengan agama lain, berakulturasi dengan budaya lokal dan bisa berdampingan dengan demokrasi. Islam di Nusantara menganut rukun Iman dan rukun Islam yang sama dengan kaum Ahlu Sunnah wal-Jama'ah. Ortodoksi Islam Nusantara sederhananya memiliki tiga unsur utama: pertama kalam (teologi) Asy'ariyah, kedua fikih Syafi'i meski juga menerima tiga mazhab fikih sunni, dan ketiga tasawuf al-Ghazali. Sedangkan ortodoksi Islam Arab Saudi hanya mengandung dua unsur yaitu pertama, kalam (teologi) Salafi-Wahabi dengan pemahaman Islam literal dan penekanan pada Islam yang murni. Kedua, fikih Hambali yang merupakan mazhab paling ketat dalam yurisprudensi Islam. ${ }^{6}$

Peranan ulama dalam masyarakat cukup beragam, kedudukan sosial ekonomi dan politik seorang ulama yang baik akan semakin menambah peran mereka dalam membina masyarakat di lingkungannya. Memang awalnya eksistensi ulama dikenal di dunia pondok pesantren, madrasah, majelis taklim, masjid maupun mushala dan juga sebagai pendidik dan pengajar agama Islam. Namun peran mereka kemudian berkembang ke berbagai bidang kehidupan masyarakat. Dengan meluasnya kiprah ulama di berbagai bidang kehidupan masyarakat, maka mereka biasa dikatakan berperan ganda. Mereka menjadi tempat curahan hati umatnya yang memerlukan bantuan berupa nasihat apa saja yang menyangkut masalah pribadi, keluarga maupun masalah umum. Masalah pribadi yang disampaikan kepada ulama itu misalnya minta doa agar usahanya lancar ingin sukses dalam pemilihan pemimpin setempat Kepala Desa anggota DPRD maupun Bupati Walikota ingin sukses dalam pendidikan yang ditempuhnya atau ingin agar tanaman di sawah terhindar dari hama dan bencana. Mereka datang kepada seorang ulama dan menceritakan apa yang dikehendakinya. Kemudian mereka meminta nasihat dan jalan keluar yang mesti mereka kerjakan, dan tidak lupa mereka meminta doa dari sang ulama itu agar apa yang mereka harapkan dapat terwujud. Masalah lain yang disampaikan kepada ulama adalah hal-hal yang bersifat gaib seperti apabila ada orang yang dianggap tidak waras disebabkan gangguan jin maka kiai itu diminta untuk mengusir jin itu dan mengobati sang penderita. Ada juga masyarakat yang menganggap bahwa kiai juga bisa menyembuhkan penyakit yang tidak jelas asal usulnya. Seorang penderita penyakit yang sudah diusahakan berobat ke dokter tetapi tidak juga sembuh maka dia akan dibawa kepada seorang kiai. Cara pengobatan biasanya dilakukan dengan memberikan air putih yang sudah diberi doa oleh kiai. Seorang kiai yang melakukan cara seperti itu tidak mau disebut sebagai dukun. Sementara yang dilakukan oleh kiai adalah penyembuhan dengan melalui doa kepada Allah Doa yang digunakan oleh kiai diyakini sebagai doa-doa yang diajarkan oleh Alquran. Selain itu ada peran lain dari ulama yang lebih formal yaitu Majelis Ulama Indonesia/MUI adalah salah satu tempat peran formal ulama dalam masyarakat baik secara vertikal maupun horizontal. Setidaknya ada tiga hal yang menjadi kegiatan ulama melalui MUI yaitu penyiar agama, pemberi nasihat kepada pemerintah dan sebagai jembatan antara penguasa dan umat.

${ }^{6}$ Sahal, A., \& Aziz, Islam Nusantara: Dari Ushul Fikh Hingga Paham Kebangsaan, (Bandung: Mizan Pustaka, 2015), hal. 170. 
Pada masa reformasi yang mengedepankan keterbukaan dan kebebasan maka hubungan agama Islam dan negara juga mengalami perubahan. Para ulama yang pada masa Orde Baru mungkin hanya sebagai penonton dalam dunia politik kemudian turun ke gelanggang untuk ikut bermain dalam perpolitikan nasional. Dalam kaitannya kiprah ulama dalam dunia politik ini maka mereka dapat digolongkan menjadi tiga kelompok;

Pertama: Mereka yang berpendapat bahwa kehidupan keagamaan dan kemasyarakatan tidak dapat dipisahkan. Islam tidak mengenal pemisahan itu, oleh karena itu menurut mereka keterlibatan ulama dalam masalah politik sehari-hari adalah suatu keharusan. Kelompok ulama inilah yang kemudian berperan langsung dalam kehidupan politik praktis, misalnya mendirikan partai politik dan ikut kampanye untuk memenangkan partai mereka. Ulama kelompok ini berusaha meraih kekuasaan politik formal, ada yang terlibat dalam kepengurusan partai politik. Mereka kemudian ikut berkompetisi untuk masuk ke Dewan Perwakilan Rakyat/DPR maupun Dewan Perwakilan Rakyat Daerah/DPRD Ada juga yang ikut memperebutkan jabatan Bupati Walikota bahkan Presiden. Kelebihan kelompok ini adalah dapat menunjukkan bahwa antara agama dan politik tidak perlu dipisahkan, keduanya dapat disatukan oleh ulama yang berpolitik praktis. Dengan perannya ini diharapkan ulama dapat memberikan warna yang baik bagi kehidupan politik dan dapat mengubah citra politik yang sering kali diidentikkan dengan kejelekan. Akan tetapi kelemahannya adalah mereka sering kali dicurigai oleh pihak lain yang berbeda aliran politiknya, akibatnya peran mereka sebagai ulama menjadi tidak aktif lagi terhadap pihak di luar kelompoknya.

Kedua: Mereka yang berpendapat bahwa kehidupan keagamaan dan kemasyarakatan termasuk politik tidak dapat dipisahkan hanya saja mereka merasa tidak perlu melibatkan diri dalam politik praktis. Kelornpok ulama ini walaupun peduli pada masalah politik dan kenegaraan tetapi tidak mau berperan sebagai pendukung salah satu partai politik secara terbuka. Dalam pemilu kelompok ulama ini ikut memilih salah satu kontestan pemilu tetapi mereka tidak ikut kampanye untuk kepentingan pemenangan suatu partai. Dengan demikian peran ulama kelompok kedua ini hanyalah mendorong berlangsungnya kehidupan politik secara baik tetapi tidak mau ambil resiko dengan terlibat secara langsung dalam dunia politik praktis. Mereka ingin menjaga cara berpolitik secara luhur, mereka beranggapan Islam hanya memberikan prinsip-prinsip kehidupan politik. Paling tidak ada tiga prinsip etis yang digariskan yaitu prinsip keadilan (al-adl), prinsip kesamaan (almusawah) dan prinsip musyawarah (as-syura 39). Namun mereka tidak mau berperan aktif untuk bereksperimen dalam dunia politik nyata, alasannya mereka tidak mau terlibat dalam konflik yang merugikan persatuan umat Islam.

Ketiga: Mereka yang tidak mau tahu dengan urusan kehidupan politik, mereka merasa kehidupan berpolitik bukan urusan ulama. Kelompok ini membatasi kiprahnya hanya dalam masalah moral keagamaan, mereka sengaja menghindari kehidupan politik karena hal itu dianggap terlalu duniawi.

Signifikansi peran ulama dalam kehidupan masyarakat Islam, ditambah loyalitas umat terhadapnya membuat pengaruh ulama sedemikian rupa, menjadi figur strategis kerjasama baik itu kalangan penguasa maupun pengusaha. Ulama dibutuhkan dalam mendampingi dan mengarahkan umat dalam menghadapi dinamika kehidupan yang 
sedemikian kompleks. Namun pengaruh dan kharisma membangun loyalitas tersebut perlahan redup, bahkan hilang, terutama di Indonesia. Kondisi ini disebabkan setidaknya oleh dua hal. Pertama: modernisasi, perkembangan teknologi informasi, pertumbuhan ekonomi, dan segala bentuk perubahan sosial yang terjadi telah menggeser fungsi dan kedudukan ulama di mata masyarakat. Kedua: gagapnya ulama mengantisipasi dan menyikapi perubahan, minimnya keteladanan, keberpihakan ulama kepada umat. Ulama lewat produk ijtihadnya, fatwanya sering tidak senafas dengan masyarakat, membuat kacau ketimbang membuat damai. Ini tidak berarti mengeneralisir, tetapi kecenderungan kuat menggejala di tengah kehidupan sekarang. Figur ulama terjebak dalam selebrasi ekonomi politik yang sarat dengan permainan keuntungan dunia, kemegahan dan kemewahan. Mereka tidak tahan berada di garis demokrasi perjuangan membela umat yang masih miskin, bodoh, terpinggirkan, tersingkirkan dalam pusaran kapitalisme ekonomi dan politik praktis. Banyak media yang telah memberikan kritik terhadap gejala ini, sebut saja keterlibatan ulama dalam politik praktis, Pilkada yang banyak memicu kontroversi. Pertimbangkan juga tema-tema sinetron yang lagi trend belakangan ini; ulama photocopy, ulama gadungan, ulama seleb, dan sejenisnya yang mengumbar kenaifan perilaku ulama. Di samping itu, saat ini ada juga diantara ulama yang mengemuka dengan membawa pemikiran baratnya. Mereka tanpa rasa takut sedikitpun memunculkan pernyataanpernyataan yang merugikan Islam dan kaum Muslimin, bahkan pada tataran tertentu penyataan-pernyataan tersebut termasuk kedalam kategori kekufuran. ${ }^{7}$

\section{Kesimpulan}

Ulama memiliki status yang sangat urgen dan posisi strategis dalam Islam. Dengan ilmu pengetahuannya, mereka memiliki rasa takwa, takut dan tunduk kepada Allah . Ulama juga memiliki pengetahuan tentang ayat-ayat Allah baik yang kauniyyah maupun quraniyah. Karena begitu khasnya posisi ulama di dalam Islam, maka tidak sulit untuk difahami kenapa ulama begitu dihormati di kalangan umat Islam, memiliki pengaruh dan membuat umat loyal terhadapnya. Peranan ulama dalam masyarakat cukup beragam, kedudukan sosial ekonomi dan politik seorang ulama yang baik akan semakin menambah peran mereka dalam membina masyarakat di lingkungannya. Memang awalnya eksistensi ulama dikenal di dunia pondok pesantren, madrasah, majelis taklim, masjid maupun mushala dan juga sebagai pendidik dan pengajar agama Islam. Namun peran mereka kemudian berkembang ke berbagai bidang kehidupan masyarakat. Dalam kegiatan formalnya, ada tiga hal yang menjadi kegiatan ulama melalui MUI yaitu penyiar agama, pemberi nasihat kepada pemerintah dan sebagai jembatan antara penguasa dan umat. Namun dalam kiprah ulama di dunia politik ini, maka mereka dapat digolongkan menjadi tiga kelompok; pertama mereka yang berpendapat bahwa kehidupan keagamaan dan kemasyarakatan tidak dapat dipisahkan dengan ikut terjun langsung di dalam politik praktis, kedua mereka yang berpendapat bahwa kehidupan keagamaan dan kemasyarakatan termasuk politik tidak dapat dipisahkan hanya saja mereka merasa tidak perlu melibatkan diri dalam politik praktis, ketiga mereka yang tidak mau tahu dengan urusan kehidupan politik, mereka merasa kehidupan berpolitik bukan urusan ulama.

${ }^{7}$ Hartono Ahmad Jaiz, Aliran dan Paham Sesat di Indonesia, (Jakarta: Pustaka al-Kautsar, 2002), hal.190-191. 


\section{Daftar Pustaka}

Abdullah bin Hisyām al-Anshāri. (2008). Syarh Qathr an-Nadā wa Baall ash-Shadā. Beirut: Dār al-Fikr.

Azra. (2002). Biografi Sosial Intelektual Ulama Perempuan: Perberdayaan Historiografi Dalam Ulama Perempuan Indonesia. Jakarta: Gramedia Pustaka Utama.

Burhanudin. (2002). Ulama Perempuan Indonesia. Jakarta: Gramedia Pustaka Utama.

Hartono Ahmad Jaiz. (2002). Aliran dan Paham Sesat di Indonesia. Jakarta: Pustaka alKautsar.

Maryadi. (1995). Eksistensi Agama pada Era Globalisasi. Jakarta: Paramadina.

Munawwir. (1997). Kamus al-Munawwir Arab-Indonesia Terlengkap. Surabaya: Pustaka Progressif.

Sahal, A., \& Aziz. (2015). Islam Nusantara: Dari Ushul Fikh Hingga Paham Kebangsaan. Bandung: Mizan Pustaka. 